\title{
Pulmonary Kaposi's sarcoma in a female patient: Case report
}

\author{
Natacha Calmeiros de Lima Petribu ${ }^{1 *}$, Mayana Silva Cisneiros $^{2}$, Glauber Barbosa de Carvalho ${ }^{3}$, Lucyana de Melo Baptista ${ }^{4}$ \\ ${ }^{1} \mathrm{MSC}-\mathrm{MD}$ and Professor of Radiology and Diagnostic Imaging, Hospital Barão de Lucena, Recife, PE, Brazil \\ ${ }^{2}$ Graduate degree - MD, Radiologist, Hospital Barão de Lucena, Recife, PE, Brazil \\ ${ }^{3}$ Graduate student - Resident Physician in Radiology and Diagnostic Imaging, Hospital Barão de Lucena, Recife, PE, Brazi \\ ${ }^{4}$ Graduate degree - MD, Medical Clinic and Cardiology Resident, Hospital Barão de Lucena, Recife, PE, Brazil
}

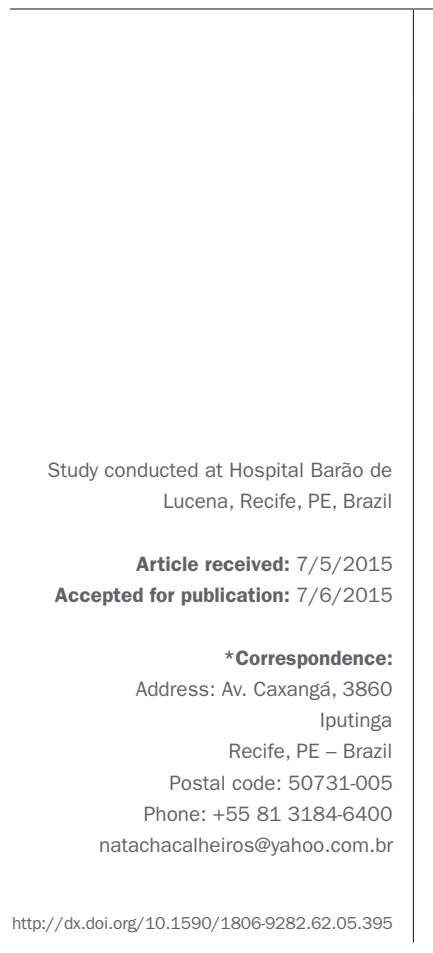

\section{SUMMARY}

Kaposi's sarcoma (KS) is a multicentric lymphoproliferative malignancy. Most of the time this tumor is confined to the skin and subcutaneous tissue, but it can present with widespread visceral involvement, such as in the lung. Pulmonary KS is the most frequent form in young adult males, in a ratio of 15:1. The disease usually affects individuals with low CD4 lymphocyte counts $(<150-200$ cells $/ \mathrm{mm}^{3}$ ). We report a case of a female patient aged 35 years, with the presence of skin lesions, self-limiting episodes of diarrhea and weight loss of $15 \mathrm{~kg}$ for nearly 9 months, progressing to persistent fever. AIDS was diagnosed and biopsy of the lesions revealed Kaposi's sarcoma. Computed tomography of the chest showed peribronchovascular thickening, areas of ground glass opacity, condensations with air bronchograms surrounded by ground glass opacity (halo sign) and bilateral pleural effusion. The diagnosis of pulmonary KS is still a challenge, especially due to the occurrence of other opportunistic diseases that may also occur concurrently. Therefore, suspecting this diagnosis based on clinical and laboratory manifestations, and even more with CT findings, is fundamental, especially in patients who already have the cutaneous form of the disease.

Keywords: Kaposi's sarcoma, HIV, acquired immunodeficiency syndrome, lung.

\section{INTRODUCTION}

Kaposi's sarcoma (KS) was first described in 1872 by Moritz Kaposi as "idiopathic multiple pigmented sarcoma of the skin". It is a multicentric lymphoproliferative malignancy macroscopically characterized by the development of grape-like tumors, often raised. Most of the time these tumors are limited to the skin and subcutaneous tissue, but they may present with widespread visceral involvement. ${ }^{1}$

The disease usually affects individuals with low CD4 lymphocyte counts $\left(<150-200\right.$ cells $\left./ \mathrm{mm}^{3}\right)$. The sites most affected by visceral involvement in AIDS-related KS are lymph nodes ( $72 \%$ of cases), lung (51\%), gastrointestinal tract (48\%), liver (34\%) and spleen (27\%). Thoracic involvement may include trachea, lymph vessels, pleura and lung parenchyma. ${ }^{2,3}$

\section{Case report}

J.M.S., 35, female, admitted into Hospital Barão de Lucena due to the presence of purplish lesions on the face, trunk, limbs, palate and right external ear, episodes of self- limiting diarrhea, and weight loss of approximately $15 \mathrm{~kg}$ in the course of approximately 9 months. AIDS diagnosis was made based on rapid HIV testing with serologic confirmation by ELISA. The patient's CD4 lymphocyte count was 64 cells $/ \mathrm{mm}^{3}$. Biopsy of the lesions with histopathological examination revealed Kaposi's sarcoma.

She had to be hospitalized due to fever and the presence of bullous impetigo and cellulitis in her left foot, treated with empiric antibiotic therapy with cephalothin. At the time, screening for other sites of infection was negative. There was no clinical improvement and therefore we chose to broaden the antibiotic therapy with ciprofloxacin and clindamycin. However, the patient continued to have daily fever peaks.

The culture of secretion from the impetigoid lesions showed growth of ciprofloxacin-resistant Pseudomonas pseudoalcaligenes, and thus cefepime was started with subsequent association of vancomycin due to persistent fever.

Antiretroviral therapy was introduced with tenofovir, lamivudine and efavirenz. Kaposi's sarcoma staging was also requested. Upper endoscopy revealed esophageal can- 
didiasis, then treated with fluconazole. Computed tomography of the chest showed peribronchovascular thickening, areas of ground glass opacity, condensations with air bronchograms surrounded by ground glass opacity (halo sign) and bilateral pleural effusion (Figures 1,2 and 3). Following guidance from the oncology team, only antiretroviral therapy was maintained for immune recovery, with subsequent evaluation regarding chemotherapy.

Two weeks after admission, the patient progressed with disorientation, hallucinations, worsening of respiratory pattern, and oliguria. She had worsening of renal function, and strong metabolic acidosis. The patient was referred to the ICU, and after central venous access puncture

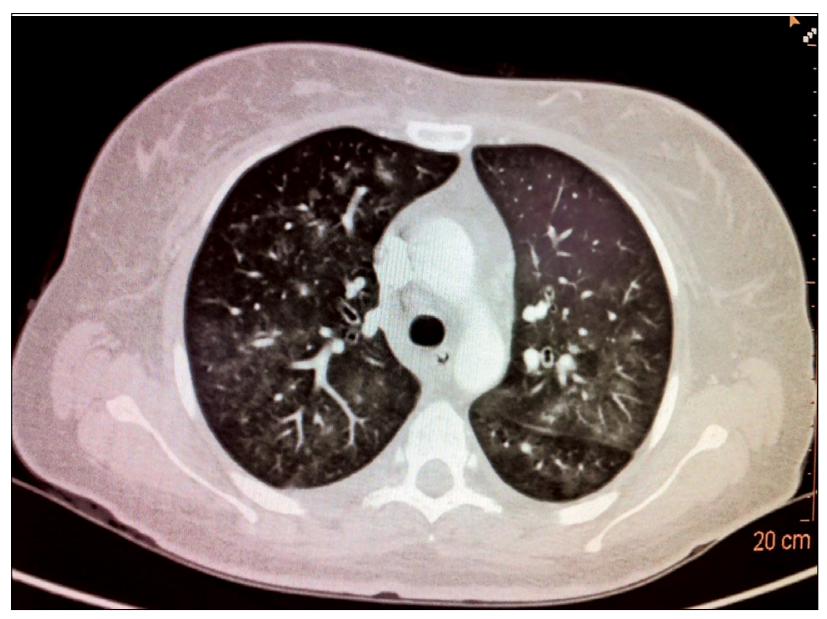

FIGURE 1 Chest CT scan, axial lung window. See areas of ground glass opacity diffusely in both lungs.

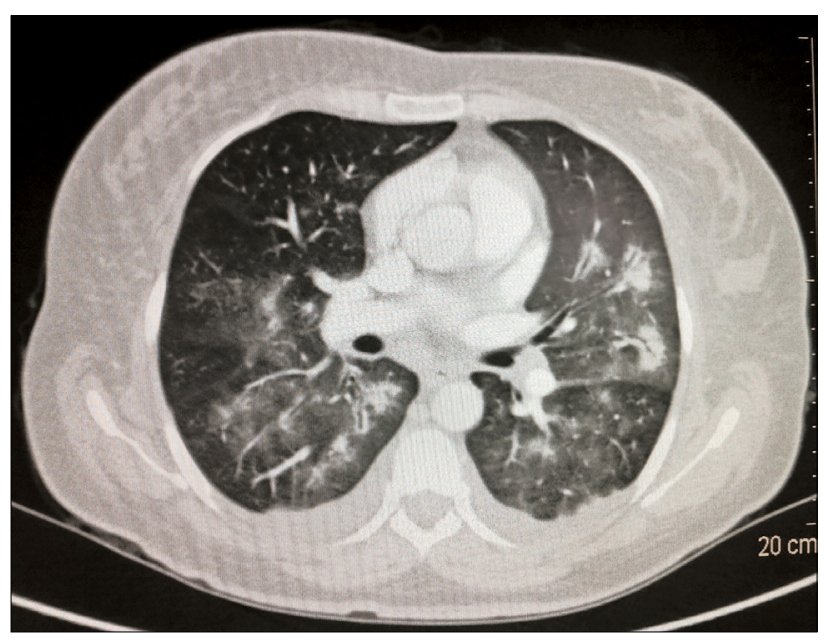

FIGURE 2 Chest CT scan, axial lung window. Some areas of consolidation with irregular margins, and a ground glass halo giving the appearance of flame. There is bilateral pleural effusion and peribronchovascular infiltrate.

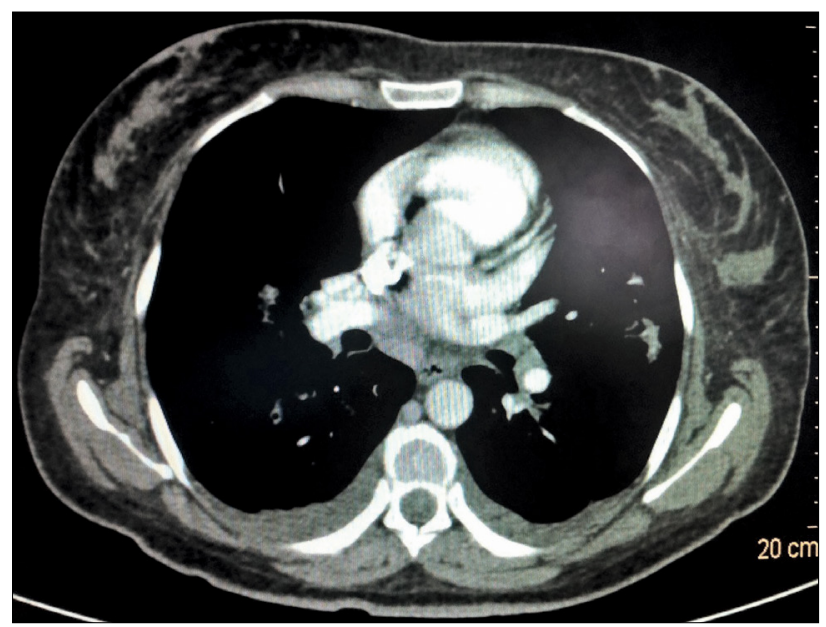

FIGURE 3 Chest CT scan, axial mediastinal window, arterial phase. See small bilateral pleural effusion and mediastinal lymph nodes with preserved size.

she progressed with respiratory failure requiring mechanical ventilation. As chest X-ray showed extensive pneumothorax, chest tube drainage was performed. Increased nitrogenous compounds and metabolic acidosis were treated with dialysis requiring vasoactive drug due to hemodynamic instability.

Due to the possible association of hallucinogenic symptoms with efavirenz and the risk of nephrotoxicity of tenofovir, the team chose to replace the Antiretroviral Therapy (ART), introducing lopinavir/ritonavir and abacavir with lamivudine. The antibiotic coverage was broadened and tuberculostatic medication was started to treat a possible disseminated tuberculosis, later discarded after a negative result of PCR tests for the disease in the blood, CSF, and urine. Cranial CT scan showed no changes, and study of CSF ruled out any association with opportunistic diseases of the central nervous system. A new CT scan of the chest revealed consolidations at the base of both lungs within air bronchograms and residual pneumothorax. The patient progressed with clinical improvement, and the tracheal tube was removed. Given that control chest X-ray showed complete lung expansion, we opted for the removal of the chest drain.

The patient continued with hallucinations and psychomotor agitation, which were explained after psychiatric evaluation as sepsis-associated delirium, then treated with quetiapine.

During hemodialysis, the patient had an episode of hypotension, followed by massive aspiration and cardiorespiratory arrest with asystole. There was no reversal after cardiopulmonary resuscitation maneuvers. 


\section{Discussion}

KS associated with infection by the human immunodeficiency virus (HIV) is common in adult homosexual and bisexual young men. ${ }^{4-6}$

Men are more affected than women in a ratio of 15:1. The annual incidence is between 0.02 and $0.06 \%$ of all malignant tumors. ${ }^{7} \mathrm{KS}$ rarely affects American or European heterosexuals, but it often occurs in African or Caribbean heterosexuals. ${ }^{8}$

Most patients with pulmonary KS already present with cutaneous lesions at the time of diagnosis; however, visceral disease may occasionally precede the skin. The most affected skin sites are the lower limbs, head and neck, and the lesions may have a varied appearance (spots, papules, nodules or plaques), all palpable and non-pruritic, with sizes ranging from millimeters to centimeters, and brownish, pink or violet color. These lesions may also be confluent and are generally symmetrical in distribution. ${ }^{16}$

The precise incidence of pulmonary KS is still not well known. Some clinical studies have shown a higher prevalence in individuals with AIDS who already had the cutaneous form of the disease (over 32\%) compared to those without it (3-13\%). ${ }^{3,9-11}$ In autopsies, however, bronchopulmonary KS was found in $47 \%$ of patients with AIDS who had the cutaneous form, which reveals a possible underdiagnosis of pulmonary involvement. ${ }^{12}$

Since the variety of opportunistic diseases is great, pulmonary involvement in SK can be difficult to diagnose. Symptoms are unspecific (cough, dyspnea, hemoptysis, chest pain) and may represent several other diseases, including tuberculosis. Pleural effusion, hypoxemia and acute respiratory failure requiring mechanical ventilation have also been reported in some cases. ${ }^{13-15}$

Kaposi's sarcoma may involve the tracheobronchial tree, the lung parenchyma and pleura. Pleural involvement occurs only in the presence of parenchymal abnormalities, just as the presence of lesions in the bronchial tree below the tracheal carina is, as a rule, accompanied by parenchymal lesions. In the lung, Kaposi's sarcoma grows along the lymph node routes, i.e. around bronchovascular sheaths, especially in the axial interstitium, interlobular septa, and pleura. The cellular infiltrate advances in the interstitium along the peribronchovascular sheaths, the pulmonary veins, and the pleural surface. From these regions, the cells proliferate as "tentacles" to the adjacent alveolar septa and fill the alveoli, forming solid nodules. ${ }^{17,18}$

The diagnosis of pulmonary KS (PKS) is still a challenge, mainly because the clinical, laboratory and radiographic findings are non-specific and cannot differentiate PKS from other lung diseases that may occur in AIDS.
Therefore, these findings should be combined with those obtained by CT scan, bronchoscopy and transbronchial biopsy. ${ }^{19}$

Differential diagnoses include: lymphoma, lung tumors, infections (such as tuberculosis, viruses and fungi), infection with Pneumocystis jirovecii and bacillary angiomatosis. $18,20,21$

Histologically, the tumor consists of vascular spaces interspersed with spindle-shaped reticuloendothelial cell, containing atypical nuclei and occasional mitoses. The vascular gaps contain erythrocytes and hemosiderin deposits. ${ }^{18}$

The findings on chest radiography are many, usually bilateral and diffuse. Reticulonodular infiltrates with predilection for hilar areas and the base of the lungs, consolidations, multiple ill-defined nodules, bilateral pleural effusion in $30 \%$ of cases, hilar and mediastinal lymph node enlargement in $10 \%$ of cases, and even normal x-rays have also been described. ${ }^{2,19-25}$ The presence of other associated lung infections may complicate the interpretation of the findings. Due to the above and the fact that the findings are not specific of PKS, radiography has the main role to dismiss lung involvement and/or monitor disease progression. ${ }^{26}$

High-resolution CT (HRCT) has higher sensitivity and specificity compared to radiography in the event of suspected diagnosis of PKS. Early findings include thickening of peribronchovascular interstitium, especially in the base of the lungs, which can even simulate other opportunistic infections of the airways. Late changes include ill-defined nodules/consolidations ("candle flame" appearance) with peribronchovascular distribution, symmetrical and bilateral, which may be surrounded by ground glass opacity (halo sign), thickening of peribronchovascular axial interstitium, interlobular septal thickening and pleural effusion. These changes were observed in our patient (Figure 3). In addition to these findings, there is also nodular thickening of fissures, subpleural nodules, hilar and mediastinal lymph node enlargement, absent in this case, which presented some mediastinal lymph nodes with preserved size. In most patients, the presence of typical nodules in $\mathrm{CT}$ and perihilar distribution of the aforementioned abnormalities justify KS being considered together with other thoracic affections in AIDS. ${ }^{2,15,18-20,25,27-32}$

\section{Conclusion}

The diagnosis of pulmonary KS is still a challenge, especially due to the occurrence of other opportunistic diseases that may also occur concurrently. Therefore, suspecting this diagnosis based on clinical and laboratory 
manifestations, and even more with CT findings, is fundamental, especially in patients who already have the cutaneous form of the disease, so that proper treatment can be initiated as soon as possible.

\section{Resumo}

Sarcoma de Kaposi pulmonar em paciente do sexo feminino: Relato de caso

O sarcoma de Kaposi (SK) é uma neoplasia angioproliferativa maligna multicêntrica. Na maioria das vezes, esse tumor restringe-se à pele e ao tecido subcutâneo, mas pode cursar com comprometimento visceral amplamente disseminado, como é o caso do pulmão. O SK pulmonar é a forma mais frequente em homens adultos jovens, em uma proporção de 15:1. A doença geralmente acomete indivíduos com baixa contagem de linfócitos CD4 ( $<150-200$ células/ $\mathrm{mm}^{3}$ ). Relatamos um caso de uma paciente do sexo feminino, 35 anos, com presença de lesões cutâneas, episódios de diarreia autolimitada e perda de peso de $15 \mathrm{~kg}$ havia aproximadamente 9 meses, evoluindo para quadro febril persistente. Foi dado o diagnóstico de aids e foi realizada biópsia das lesões evidenciando sarcoma de Kaposi. A tomografia computadorizada do tórax evidenciou imagens de espessamento peribroncovascular, áreas de vidro fosco, condensações com broncogramas aéreos circundados por área de vidro fosco (sinal do halo) e derrame pleural bilateral. O diagnóstico da forma pulmonar de SK ainda é um desafio, principalmente pela ocorrência de outras doenças oportunistas que, inclusive, podem ocorrer de forma concomitante. Portanto, a suspeição desse diagnóstico pelas manifestações clínicas, laboratoriais e, principalmente, tomográficas é de fundamental importância, sobretudo em pacientes que já apresentam a forma cutânea da doença.

Palavras-chave: sarcoma de Kaposi, HIV, síndrome de imunodeficiência adquirida, pulmão.

\section{REFERENCES}

1. Kalil JA, Jovino MAC, Papaiordanou F, Arriaga M, Ribeiro Jr MAF. Sarcoma de Kaposi em membros inferiores: relato de caso. J Vasc Bras. 2010; 9(4):261-5.

2. Restrepo CS, Martínez S, Lemos JA, Carrillo JA, Lemos DF, Ojeda P, et al. Imaging manifestations of Kaposi sarcoma. Radiographics. 2006; 26(4):1169-85.

3. Zibrak JD, Silvestri RC, Costello P, Marlink R, Jensen WA, Robins A, et al. Bronchoscopic and radiographic features of Kapsosi's sarcoma involving the respiratory tract. Chest. 1986; 90(4):476-9.

4. Fonseca BAL, Bollela, VR, da Justa Neto P. Sarcoma de Kaposi e síndrome da imunodeficiência adquirida: características desta associação, incluindo novos conceitos sobre patogênese e tratamento. Medicina, Ribeirão Preto. 1999; 32:26-39.

5. Patrikidou A, Vahtsevanos K, Charalambidou M, Valeri RM, Xirou P, Antoniades K. Non-AIDS Kaposi's sarcoma in the head and neck area. Head Neck. 2009; 31(2):260-8.
6. Friedman-Kien AE, Saltzman BR. Clinical manifestations of classical, endemic African, and epidemic AIDS-associated Kaposi's sarcoma. J Am Acad Dermatol. 1990; 22 (6 Pt 2):1237-50.

7. Antman K, Chang Y. Kaposi's sarcoma. N Engl J Med. 2000; 342(14):1027-38

8. Sitas F, Newton R. Kaposi's sarcoma in South Africa. J Natl Cancer Inst Monogr. 2001; (28):1-4.

9. Murray JF, Felton CP, Garay SM, Gottlieb MS, Hopewell PC, Stover DE, et al. Pulmonary complications of the acquired immunodeficiency syndrome. Report of a National Heart, Lung, and Blood Institute workshop. N Engl J Med. 1984; 310(25):1682-8.

10. Garay SM, Belenko M, Fazzini E, Schinella R. Pulmonary manifestations of Kaposi's sarcoma. Chest. 1987; 91(1):39-43.

11. Gill PS, Akil B, Colletti P, Rarick M, Loureiro C, Bernstein-Singer M, et al. Pulmonary Kaposi's sarcoma: clinical findings and results of therapy. Am J Med. 1989; 87(1):57-61.

12. Meduri GU, Stover DE, Lee M, Myskowski PL, Carvelli JF, Zaman MB. Pulmonary Kaposi's sarcoma in the acquired immunodeficiency syndrome. Clinical, radiographic, and pathologic manifestations. Am J Med. 1986; 81(1):11-8.

13. Miller RF, Tomlinson MC, Cottrill CP, Donald JJ, Spittle MF, Semple SJ. Bronchopulmonary Kaposi's sarcoma in patients with AIDS. Thorax. 1992; 47(9):721-5.

14. Arruda E, Jacome AA, Toscano AL, Silvestrini AA, Rêgo AS, Wiermann EG, et al. Consensus of the Brazilian Society of Infectious Diseases and Brazilian Society of Clinical Oncology on the management and treatment of Kaposi's sarcoma. Braz J Infect Dis. 2014; 18(3):315-26.

15. Cadranel J, Naccache J, Wislez M, Mayaud C. Pulmonary malignancies in the immunocompromised patient. Respiration. 1999, 66(4):289-309.

16. Pantanowitz L, Dezube BJ. Kaposi sarcoma in unusual locations. BMC Cancer. 2008; 8:190-199.

17. Marchiori E, Valiante PM, Sales AR, Capone D, Moraes HP, Santos MLO Sarcoma de Kaposi pulmonar: correlação da tomografia computadorizada de alta resolução com a anatomopatologia. Rev Imagem. 2000; 22:63-7.

18. McGuinness G. Changing trends in the pulmonary manifestations of AIDS. Radiol Clin North Am. 1997; 35(5):1029-82.

19. Kang EY, Staples CA, McGuinness G, Primack SL, Müller NL. Detection and differential diagnosis of pulmonary infections and tumors in patients with AIDS: value of chest radiography versus CT. AJR Am J Roentgenol. 1996; 166(1):15-9.

20. Hartman TE, Primack SL, Muller NL, Staples CA. Diagnosis of thoracic complications in AIDS: accuracy of CT. AJR Am J Roentgenol. 1994; 162(3):547-53.

21. Moore EH, Russell LA, Klein JS, White CS, McGuinness G, Davis LG, et al. Bacillary angiomatosis in patients with AIDS: multiorgan imaging findings. Radiology. 1995; 197(1):67-72.

22. Mann SG. Kaposi's sarcoma. AJR Am J Roentgenol. 1974; 121(4):793-9.

23. Leibowitz MR, Dagliotti M, Smith E, Murray TF. Rapidly fatal lymphangiomalike Kaposi's sarcoma. Histopathology. 1980; 4(5):559-66.

24. Davis SD, Henschke CI, Chamides BK, Westcott JL. Intrathoracic Kaposi sarcoma in AIDS patients: radiographic-pathologic correlation. Radiology. 1987; 163(2):495-500.

25. McGuinness G, Gruden JF, Bhalla M, Harkin TJ, Jagirdar JS, Naidich DP. AIDS-related airway disease. AJR Am J Roentgenol. 1997; 168(1):67-77.

26. O'Mahony D, Gandjbakhche AH, Hassan M, Vogel A, Yarchoan R. Imaging techniques for Kaposi's sarcoma. J HIV Ther. 2008; 13(3):65-71.

27. Huang L, Schnapp LM, Gruden JF, Hopewell PC, Stansell JD. Presentation of AIDS-related pulmonary Kaposi's sarcoma diagnosed by bronchoscopy. Am J Respir Crit Care Med. 1996; 153(4 Pt 1):1385-90.

28. Gruden JF, Huang L, Webb WR, Gamsu G, Hopewell PC, Sides DM. AIDSrelated Kaposi sarcoma of the lung: radiographic findings and staging system with bronchoscopic correlation. Radiology. 1995; 195(2):545-52.

29. Khalil AM, Carette MF, Cadranel JL, Mayaud CM, Bigot JM. Intrathoracic Kaposi's sarcoma. CT findings. Chest. 1995; 108(6):1622-6.

30. Marchiori E, Müller NL, Soares Souza A Jr, Escuissato DL, Gasparetto EL, Franquet T. Pulmonary disease in patients with AIDS: high resolution CT and pathologic findings. AJR Am J Roentgenol. 2005; 184(3):757-64.

31. da Silva Filho FP, Marchiori E, Valiante PM, Escuissato DL, Gasparetto TD. AIDS-related Kaposi sarcoma of the lung presenting with a "crazy-paving" pattern on high-resolution CT: imaging and pathologic findings. J Thorac Imaging. 2008; 23(2):135-7.

32. Naidich DP, McGuinness G. Pulmonary manifestations of AIDS: CT and radiographic correlations. Radiol Clin North Am. 1991; 29(5):999-1017. 